Vol. 10 (2001): 285-294.

\title{
Land use response to agricultural policy and market movements on Finnish dairy-farms
}

Jarkko K. Niemi and Kyösti Pietola

MTT Agrifood Research Finland, Economic Research, PO Box 3, FIN-00411 Helsinki, Finland, e-mail: jarkko.niemi@mtt.fi

\begin{abstract}
This study estimates an econometric model for land allocation on Finnish dairy-farms in 1989-1997. Land allocation equations are estimated jointly with the demand of purchased feeds and the supply for milk. The model is used to test how agricultural policy reforms have changed land allocation, animal feeding, and the supply for milk on Finnish dairy-farms.

The results suggest that land allocations respond inelastically to the changes in income subsidies paid through the land areas. The use of feed concentrates in milk cows' diet has increased mainly because feed concentrate prices have decreased, rather than through the effects of acreage-based income subsidies on land allocations. At the same time, feed grain production has decreased.

Farm size has an important effect on dairy-farm land use. Farmers, who have expanded milk production, have specialised in roughage production. The diet of cows has been intensified by purchasing more feed concentrates. The results also suggest that tradable milk quotas have allowed for a significant re-allocation of milk output between farms. The milk output turned out to be endogenous over the period of tradable milk quotas (1994-1997).
\end{abstract}

Key words: land use, econometric models, milk production, roughage, concentrates, prices, subsidies

\section{Introduction}

Since late 1980s, Finnish dairy-farms have been confronted with large agricultural policy reforms and shifting market regimes. Producer prices have been systematically decreased and the resulting income losses have been, at least partially, compensated to farmers through direct income subsidies. These income subsidies are paid according to the number of animals and according to the farm's arable land area. The subsidy rates depend on the location of the farm. The area subsidy rates depend also on the crops cultivated. A hectare of land allocated to feed grains (which are considered as in farm produced feed concentrates) is, for example, entitled to a different subsidy rate to a hectare of land allocated to roughage, such as pasture, silage and hay.

These policy reforms have significantly changed farmer incentives to supply a healthy 


\section{Niemi, J. \& Pietola, K. Land use response to agricultural policy and market movements}

feed ration for milk cows through two effects: the subsidy effect and the price effect. It is expected that the direct income payments have changed the opportunity cost of allocating land to roughage. Ryhänen et al. (1996), for example, conclude that the price and subsidy rate changes have increased farmers incentives to substitute grain for roughage in milk cow's feed ration. Their results also suggest that, in 19951999, higher subsidy rates encouraged farmers to grow grain instead of roughage but that optimal decisions on land allocation and feed rations should be made individually according to farm specific conditions. The results of $\mathrm{Wu}$ and Brorsen (1995) and Lidman and Bawden (1974) also support the view that land allocations can be elastic with respect to governmental actions such as subsidy policies. If a policy favours one crop to another, there may be an allocation of land and other resources to that particular crop (von Massow and Weersink 1993).

The farm land allocation and the demand for feed concentrates bought outside the farm depend also on relative prices (e.g. Lichtenberg 1989, Wu and Brorsen 1995, Hardie and Parks 1997). Conditional on certain land quality, the decreasing grain and processed feed concentrate prices combined with increasing production costs may have increased farmer incentives to increase grain and other feed concentrate purchases. Usually, feed grain and processed feed concentrates are bought to supplement feeding and, particularly, to supply richer energy and protein feeds for cows. Therefore, large changes in relative prices of feed concentrates and roughage may cause significant changes in dairy-farm land use and milk cow's diet. In a high cost country such as Finland, there are good reasons to be concerned that the subsidy and price effects have increased the share of feed concentrates in the optimal feeding ratios even in the extent that animal welfare is decreased.

This study estimates farmer response to subsidy and price movements in Finland using farm data over the period of 1989-1997. The goal is to test how agricultural policy reforms have changed off-farm purchases of feed concentrates and the on-farm feed supply in terms of land allocated to different feed crops. These policy effects have not been statistically tested before. The results will, therefore, add valuable information on guiding policies that support farmer income and also promote production practices maintaining animal welfare through the supply of healthy diet for cows.

Land allocations are estimated jointly with the demand for purchased feed concentrates and the supply for milk. In this structure, we can identify separately the subsidy effect and the price effect. These effects on land allocation can be separated even if the policy decision to compensate decreasing price subsidy by increasing land subsidy were made simultaneously and connected to each others. If the subsidy changes have increased the amount of grains in the feed ration, it necessarily has implications on the land allocations, because the subsidies, affecting the supply for feeds, are paid according to these land allocations. If, on the other hand, price movements have been the driving force, they may have increased feed concentrates in the optimal feeding through increased purchases of feed concentrates even if adjustments in land allocations have been negligible. The estimation results will also provide information on how land allocation changes when farm size grows.

In 1993, milk quotas became tradable and the maximum milk output per farm may have become endogenous. Milk output is endogenous if the quota trade significantly re-allocates milk production rights between farms. Therefore, the model is estimated by Two-Stage Least Squares and endogeneity of the milk output in 1994-1997 is tested for by Hausmann's specification test.

\section{The model}

\section{Constrained profit maximisation}

In economic theory, prices include information about production decisions when firms are max- 
Vol. 10 (2001): 285-294.

imising profits without significant constraints. Nevertheless, several constraints, such as (quasi) fixed farm characteristics and production rights retard farmers from fully adjusting to the observed price movements. Therefore, the underlying behaviour behind our empirical model follows a certain constrained profit maximisation problem. Over the period of non-tradable milk production rights, the maximisation is constrained by the fixed farm characteristics and by the exogenously determined milk output. When the milk quotas became tradable, the constraints include only the fixed farm characteristics. Milk output is adjusted to the prices, subsidies and the fixed farm characteristics.

Under this behavioural setting, land allocations, input demands and output supplies can be modelled in the reduced form as a function of the constraints, current prices and subsidy rates and their expectations. These constraints include fixed factors, such as farm technology, total land area, and non-tradable production rights.

The model is based on the standard approach of having exogenous input and output prices. Exogenous input prices, such as feed prices, are justified since the agricultural input market has a large number of buyers (farmers). Similarly, milk market has a large number of relatively small suppliers (farmers). An individual farmer among a large number of farmers does not have market power to affect the market prices. It is likely that correlation between the prices and the error term of econometric model is negligible and insignificant.

In this study we assume rational expectations such that current prices and subsidy rates include all information on future prices and subsidy rates. This assumption has been widely used in the agricultural economic literature (e.g. Vasavada and Chambers 1986). The assumption is seemingly restrictive but, in practice, it does not result in much losses of generality. Modelling farmer behaviour as a function of current prices generalises to all expectations structures (static and non-static), provided that expectations satisfy the first order Markov property in such a way that future price expectations are formed according to the current prices (Pietola and Myers 2000).

\section{Land allocation equations}

Land allocation can be modelled either in levels (e.g. hectares) or as shares from the farm's total land area. Houck and Ryan (1972) estimate land allocations in levels whereas $\mathrm{Wu}$ and Brorsen (1995) specify allocations in the shares form. Efficiency of the estimates can be increased in both specifications through a similar adding up constraint. Land allocations necessarily sum up to the farms total land area. The allocation shares add up to one. Since both of these specifications give similar results in the estimation problem of this study, we only report here the levels form specification.

In the general form, the land allocation for crop $i$ at time $t\left(A_{i, t}\right)$ on a farm is determined by a function $\left(F_{i}\right)$

$$
\begin{aligned}
& \text { (1) } A_{i, t}=F_{i}\left(P_{t}, W_{t}, G_{t}, Q_{j, t}, M_{j, t}\right)+u_{i, t}, \\
& \sum_{i=1}^{n} A_{i, t}=A_{\text {total }}
\end{aligned}
$$

where $P_{t}$ measures output prices, $W_{t}$ is input prices, $G_{t}$ is acreage based subsidies, $Q_{j, t}$ includes predetermined farm characteristics of farm $j, M_{j, t}$ is the predetermined milk output of farm $j$, and $u_{i, t}$ is an error. The adding up identity sums the land allocations up to the farms total land area $\left(A_{\text {total }}\right)$.

Allocations are estimated for aggregated roughage area (pasture, silage and hay) $(i=1)$ and aggregated feed grains area (barley and oats) $(i=2)$. Endogenous allocations to other crops are negligible on the sample farms (the data are described in section 3). These allocations and compulsory set aside areas are subtracted from the total land area. In other words, the predetermined land area used in estimation is the land area allocated to the feed crops $\left(A_{\text {total feeds }}\right.$ ).

A dummy variable $d_{t}$ is used to identify the time period before and after the milk quota exchange liberalisation. When the milk quotas were tradable (1994-1997), the dummy variable has 


\section{Niemi, J. \& Pietola, K. Land use response to agricultural policy and market movements}

value one $\left(d_{t}=1\right)$. Otherwise it has value zero $\left(d_{t}=0\right) . M_{t}$ is the milk output during the regime when milk quotas were non-tradable. $M_{t}^{e}$ is the (possibly endogenous) milk output during the time period, when the milk quotas were tradable. Under these definitions, the estimated allocation equations are specified in the reduced form as ${ }^{1}$ :

$$
\begin{aligned}
& A_{i, t}=Z_{j, t}^{-P} \beta^{A}+\left(1-d_{t}\right) M_{j, t} \gamma_{1}^{A}+d_{t} M_{j, t}^{e} \gamma_{2}^{A}+u_{i, t}, \\
& \text { for } i=1,2 \text { and subject to } A_{1}+ \\
& A_{2} \equiv A_{\text {total feeds }},
\end{aligned}
$$

where $Z_{t}^{-P}$ includes exogenous subsidy rates and prices, excluding the price of milk and the price of milk quota, which are used to identify endogenous milk supply. The term $Z_{t}^{-P}$ also includes the amount of farm capital, labour input, the farm's land area, and the location of the farm $j$. The terms $\beta^{A}$ and $\gamma^{A}$ are parameters.

Either one of the two allocations is redundant in (2) through the adding up constraint. Therefore, the roughage area is estimated in (2) and the feed grain area is calculated through the constraint $A_{1}+A_{2} \equiv A_{\text {total feeds }}$. Estimating the grain allocation and computing the roughage allocation through the adding up constraint results in similar estimates as the specification reported here.

\section{The demand for purchased feeds}

We model the amount of purchased feeds by a separate equation, since the land allocations determine only the amount of feeds produced on farms (conditional on fixed yields per hectare). Demand for purchased feeds on a dairy-farm is also the standard derived demand and it is par-

1 The structural form derivation of the allocation equations, the milk supply, and the feed demand, would be applying the envelope theorem to a certain parametrically specified profit function. The reduced form presentation adapted in this paper is consistent with the structural form. The reduced form is empirically tractable but, as pointed out by the referee, has a cost of ignoring parameter restrictions between the demands, the supplies, and the profit. allel to the land allocation equations. Therefore, the demand for the purchased feed concentrates $\left(X_{t}^{R}\right)$ is explained by the same explanatory variables as the land allocation. The equation takes the form:

$$
X_{t}^{R}=Z_{t}^{-P} \beta^{R}+\left(1-d_{t}\right) M_{t} \gamma_{1}^{R}+d_{t} M_{t}^{e} \gamma_{2}^{R}+v_{t},
$$

where $\mathrm{v}_{\mathrm{t}}$ is an error and $\beta^{R}, \gamma_{1}^{R}$ and $\gamma_{2}^{R}$ are parameters.

\section{The supply for milk}

Milk supply and land allocations are linked to each other on dairy-farms, since land is used mainly to produce feeds for the ruminants. If the supply for milk is endogenously chosen by farmers it will correlate with the error term in equation (2) and the parameter estimates would no longer be consistent nor efficient. Under this endogeneity problem, consistent and efficient estimates could be obtained by estimating the allocation equations in the reduced form and including the price of milk in the set of explanatory variables (e.g. Miller and Platinga 1999). Nevertheless, in our data, the amount of milk produced on individual farms are bounded from above by the milk production rights (milk quotas). Under the quota system, milk prices are not sufficient instruments to control for milk supply.

In this study, more structure in modelling the effects of milk supply is added. It is assumed that the milk supply was exogenous over the period when milk quotas were non-tradable (1989-1993). This assumption is justified, since milk output on most farms was close to their quotas. In 1994 and thereafter the milk quotas have been tradable and the milk supply is likely be at least partially endogenous. Over the sample period when milk quotas were tradable (i.e. $\left.d_{t}=1\right)$ the milk supply is modelled as:

$$
d_{t} M_{t}^{e}=d_{t} Z_{t} \beta^{M}+\varepsilon_{t}
$$

where $\beta^{M}$ is a vector of parameters, $\varepsilon_{t}$ is an error, and $Z_{t}=\left(Z_{t}^{-P}, P_{t}\right)$. The vector $Z_{t}^{-P}$ is the same set of explanatory variables as in the land allo- 
Vol. 10 (2001): 285-294.

cation equations. The vector $P_{t}$ includes the price of milk and the price of milk quota. These prices identify the milk supply equation. They also provide the necessary over-identification restrictions to test for endogeneity of the milk supply in the land allocation equations.

\section{Estimation method}

The econometric model includes three equations: equations (2), (3) and (4). They are estimated by Two-Stage Least Squares (2SLS), because the milk supply $\left(M_{t}^{e}\right)$ might be endogenous. Endogenous explanatory variables correlate with the error term and they result in inconsistent estimates of the land allocation and feed demand equations. The 2SLS estimation is the standard approach to solve the endogeneity problem and generate unbiased estimates (e.g. Wooldridge 2000). Estimation is done at two stages. At the first stage, the fitted value $\hat{M}_{t}^{e}$ for milk supply is estimated in Equation 4. At the second stage, observations for endogenous milk supply $M_{t}^{e}$ are replaced by the fitted values $\hat{M}_{t}^{e}$. Then the equations for land use (equation 2) and demand for purchased feed concentrates (equation 3 ) are estimated.

Hausman specification test is used to test for the endogeneity of the milk supply. Under the null hypothesis, the milk supply $M_{t}^{e}$ is exogenous in (2) and it does not correlate with the error term $u$. The alternative hypothesis is that $M_{t}^{e}$ and $u$ correlate and the fitted variable $\hat{M}_{t}^{e}$ has to be estimated. Even if the null hypothesis holds, 2SLS results consistent estimates but they are inefficient (Pindyck and Rubinfeld 1991, p. 303-304).

The test was carried out with the following steps. The milk supply (4) was estimated by Ordinary Least Squares (OLS) to obtain the residuals $\hat{\varepsilon}_{t}$. Then, the land use equation was estimated by OLS with observed milk supply and an additional explanatory variable $\hat{\varepsilon}_{t}$. If the estimated coefficient for $\hat{\varepsilon}_{t}$ is statistically significant at a small significance level, the conclusion is that null hypothesis must be rejected and $M_{t}^{e}$ is endogenous (Wooldridge 2000, p. 483-484).
The standard errors of the elasticity estimates are estimated by transformed models. A transformed model is obtained by first solving the elasticity equation (evaluated around the sample means) for a parameter. The parameter can be chosen arbitrarily and it also appears in the original estimating equations. Then, in the second step the right hand side of the resulting equation is substituted for the corresponding parameter in the original estimating equation. Like terms are collected and this transformed model, which has the elasticity estimate as a parameter, is re-estimated. The standard error of the elasticity estimate is now obtained as the standard errors of other model parameters.

The unbalanced panel data were pooled across time in estimation without using more advanced panel estimation methods for several reasons. First, we can get consistent estimators in the pooled data under fairly general conditions, and pooling the data raises only minor statistical complications (Wooldridge 2000). We did not use the fixed effect estimation, based either on the differenced or demeaned data, because then we would have lost many important features of the model, such as the identification of farm specific but time constant factors. In practice, important variables as, for example, farm land area and milk production under quota could have been only poorly identified in the fixed effect model since they have only a small variation over time on individual farms. The random effect specification was not used since we were not willing to accept a very restrictive assumption that the time constant individual effects are uncorrelated with all explanatory variables in the model (Hsiao 1993).

\section{The data}

The unbalanced panel data are 3,351 dairy-farm observations in the Farm Accountancy Data Network (FADN) in 1989-1997. Over the period of tradable milk quotas (1994-1997), the number 
Niemi, J. \& Pietola, K. Land use response to agricultural policy and market movements

Table 1. Feed grain, roughage and set-aside area (ha/farm), farm size (ha/farm) and quantity index for concentrate purchases $(1989=1)$ in Finnish dairy-farm records 1989-1997.

\begin{tabular}{lccccr}
\hline & Feed Grain & Roughage & Set-aside & Farm area & Concentrate purchases \\
\hline 1989 & 8.64 & 17.71 & 0.57 & 27.78 & 1 \\
1990 & 8.49 & 17.53 & 0.65 & 27.35 & 0.85 \\
1991 & 6.77 & 17.54 & 3.77 & 28.52 & 0.81 \\
1992 & 6.25 & 18.76 & 2.85 & 28.46 & 0.98 \\
1993 & 5.86 & 18.60 & 3.03 & 28.28 & 1.02 \\
1994 & 5.99 & 19.47 & 3.31 & 29.31 & 1.06 \\
1995 & 7.33 & 20.95 & 0.90 & 29.69 & 0.79 \\
1996 & 8.31 & 21.44 & 0.65 & 30.91 & 1.01 \\
1997 & 9.12 & 21.89 & 0.65 & 32.36 & 1.01 \\
Average & 7.4 & 19.3 & 1.8 & 29.2 & 0.95 \\
\hline
\end{tabular}

of observations is 1,549 . The number of observations varies annually between 342 and 393 .

The sample farms received more than $50 \%$ of their revenue from milk sales. The data are stratified by farm location into four groups that are identified in the estimation by dummy variables. Land allocation is measured by land area used to grow roughage or feed grains. The sample farms have allocated most of land to these two groups of crops.

The amount of purchased feed concentrates $\left(X_{t}^{R}\right)$ is measured by a quantity index. It is calculated by dividing concentrate expenses by the Törnqvist price index for concentrates (MMM 1993, 1998). The quantity index for milk output is also calculated by dividing the revenues from milk by the annual average price of milk. These quantity indices are quality corrected such that a higher quality (and higher price received by a farm) implies larger value for the quantity index.

The average feed grain acreage in Finnish bookkeeping dairy-farms decreased significantly in the early 1990s but began to increase again in 1994 (Table 1). Probably one of the main reasons for the decrease was the obligatory set-aside regulation.

The Finnish EU-membership changed subsidy and set-aside regulations significantly in 1995. The average roughage area increased quite steadily in the 1990s.

The annual data on subsidy rates are from Finnish Agriculture-yearbooks (Kettunen 1995,
1997, 1998) and prices are from the official statistics of Finland (MMM 1993, 1998). The subsidy rates vary between years and also between farms since they depend on farm specific characteristics, such as the farm location. Nevertheless, these farm specific subsidy rates are still exogenously determined for each farmer. Feed barley price is used as an index for feed grain prices. Purchased concentrates price is measured by the purchased concentrate price index and the fertiliser price index is used as an indicator for the crop production cost. Milk price is the farm gate price such that it includes all price subsidies and other price adjustments affecting the price paid for farmers. Milk quota price is the average quota price within 16 rural economic centres. Thus, the price of milk quota also depends on the location of the farm. Quota prices differ between locations since the quotas cannot be traded between the 16 areas. Only within an area is trade allowed.

\section{Results}

\section{Parameter estimates}

Most of the parameter estimates in the land allocation and in the purchased feed concentrates demand equations differ significantly from zero 
Vol. 10 (2001): 285-294.

Table 2. Estimation results for forage acreage and concentrated feed demand.

\begin{tabular}{lccrrr}
\hline & \multicolumn{2}{c}{ Forage equation } & & \multicolumn{2}{c}{ Feed concentrates equation } \\
\cline { 2 - 3 } \cline { 5 - 6 } Variable & Coefficient & t-statistic & & Coefficient & t-statistic \\
\hline Farm Capital, 100 000 mk & 2.171352 & 4.583 & & 199.15017 & 5.299 \\
Labour, 1 000 h/year & -0.056583 & -0.628 & & -7.894555 & -1.105 \\
Farm Total Acreage, ha & 0.368217 & 26.303 & & -11.556548 & -10.406 \\
Milk Output 1989 - 1993, 100 000 liter/year & 5.182527 & 6.655 & & 1085.537824 & 17.573 \\
Milk Output 1994 - 1997, 100 000 liter/year & 5.218508 & 5.714 & & 1124.448425 & 15.521 \\
Feed Grain Price, mk/kg & -1.738067 & -3.474 & & 162.306418 & 4.089 \\
Fertiliser Price Index & -0.015047 & -2.544 & & 0.017527 & 0.037 \\
Concentrated Feed Price Index & -0.01115 & -0.985 & & -8.746234 & -9.744 \\
Forage Subsidy, 1 000 mk/ha & 2.549709 & 4.042 & & 35.121313 & 0.702 \\
Feed Grain Subsidy, 1 000 mk/ha & -1.646857 & -2.57 & & 60.882049 & 1.198 \\
Set-aside Compensation, 1 000 mk/ha & -1.028777 & -6.068 & & -23.468686 & -1.745 \\
Dummy Region, South Finland & -5.523716 & -22.645 & & -392.568716 & -20.288 \\
Dummy Region, Ostrobothnia & -3.868212 & -16.622 & & -127.671027 & -6.916 \\
Dummy Region, Middle and East Finland & -4.099412 & -18.774 & & -326.86648 & -18.871 \\
Constant & 12.883142 & 9.831 & & 766.526315 & 7.373 \\
\hline Coefficient of Determination R ${ }^{2}$ & 0.70 & & & 0.41 & \\
Standard Error of Regression & 4.38373 & & & 347.75258 & \\
F-statistic & 555.744 & & & 162.893 & \\
\hline
\end{tabular}

at $5 \%$ risk level (Table 2). Thus, land allocation and the demand for feeds respond significantly to price and subsidy movements. Allocations depend also on farm characteristics, such as farm capital and land endowment. As expected, also farm location and compensation to set-aside are important determinants in dairy-farm land use and feed demand.

Coefficient of determination $\left(\mathrm{R}^{2}\right)$ suggests that the estimated model performs well within the sample in explaining the dairy-farm land allocations and feed demands. Thus, the model provides strong grounds in drawing conclusions on farmer behaviour in the full population. The overall performance of the model is robust to alternative functional specifications.

\section{Endogeneity of the milk output}

As explained above, Hausmann specification test was used in testing for endogeneity of the milk output in the land allocation and in the feed demand equations. At the first stage, the error term in the milk supply equation was estimated. Then, the land allocation and the feed demand were estimated augmenting the models by the residual of the milk supply equation.

Endogeneity was tested for in the data that span the period when milk quotas were tradable, i.e. in 1994-1997. For numerical identification reasons, a price variable had to be dropped in estimating the test statistics. Therefore, the tests were carried out by changing the variable dropped in the model. Depending on the variable dropped, the t-statistics was estimated at $-4.33,4.11$ and 2.64. These statistics signal that the test result is independent on the variable dropped in estimation. In all cases, the test coefficient is statistically significant at a small risk level. Therefore, milk output was endogenous on Finnish bookkeeping farms in 1994-1997.

\section{Elasticity estimates}

Elasticity estimates are evaluated at sample averages and most of the estimates are significant 
Niemi, J. \& Pietola, K. Land use response to agricultural policy and market movements

Table 3. Elasticity of land allocations and purchased feed concentrates and standard errors of the elasticity estimates.

\begin{tabular}{|c|c|c|c|c|c|c|}
\hline & \multicolumn{2}{|c|}{ Roughage acreage } & \multicolumn{2}{|c|}{ Feed grain acreage } & \multicolumn{2}{|c|}{ Feed concentrates } \\
\hline & Elasticity & $\mathrm{SE}^{\mathrm{a})}$ & Elasticity & $\mathrm{SE}^{\mathrm{a})}$ & Elasticity & $\mathrm{SE}^{\mathrm{a})}$ \\
\hline Feed grain price & -0.12 & 0.035 & 0.32 & 0.091 & 0.28 & 0.068 \\
\hline Concentrated feed price & -0.054 & 0.054 & 0.14 & 0.14 & -1.04 & 0.11 \\
\hline Fertiliser price & -0.085 & 0.034 & 0.22 & 0.087 & 0.0025 & 0.066 \\
\hline Roughage land subsidy & 0.16 & 0.040 & -0.42 & 0.10 & 0.037 & 0.078 \\
\hline Feed grain land subsidy & -0.11 & 0.044 & 0.29 & 0.11 & 0.10 & 0.086 \\
\hline Farm acreage & 0.56 & 0.021 & 1.45 & 0.055 & -0.43 & 0.041 \\
\hline Milk output 1989-1993 & 0.15 & 0.022 & -0.38 & 0.058 & 0.76 & 0.043 \\
\hline Milk output 1994-1997 & 0.12 & 0.020 & -0.30 & 0.053 & 0.62 & 0.040 \\
\hline Labour & -0.014 & 0.023 & 0.037 & 0.059 & -0.049 & 0.044 \\
\hline Farm capital & 0.032 & 0.007 & -0.083 & 0.018 & 0.072 & 0.014 \\
\hline
\end{tabular}

a) $\mathrm{SE}$ is standard error of the elasticity estimate

(Table 3). Increasing feed grain and manufactured feed concentrates prices increase grain areas and decrease roughage areas. An increasing fertiliser price shifts land from roughage to grains, because cultivation of roughage is more intensive than cultivation of grains. If subsidy rates granted to roughage areas are increased, land will be shifted from grains to roughage. The subsidies on grain areas have the opposite effect with similar magnitude.

Elasticity of land allocation is almost identical with respect to changes in the feed grain price and with respect to the subsidy rate for land allocated to feed grain. At prices and subsidies after Finland's entry to the EU, the elasticity of similar sizes is plausible since both feed grain prices and subsidy rates have equal importance in farmer income. Before the EU entry (and around the sample means) these elasticity estimates imply, however, asymmetric absolute income effects. With high feed grain prices, the absolute income effects are asymmetric since changes in subsidy rates have only direct effects on allocations and farmer income. But relative changes in high feed grain prices also have indirect spill over effects on the feed prices and on the feed purchases.

The overall conclusion from the elasticity estimates is, nevertheless, that the allocations respond quite inelastically to the movements in prices and subsidy rates. The elasticity values are generally smaller than 0.5 . The only elastic price response is in the demand of purchased feed concentrates with respect to its own price. The demand for purchased feed concentrates increases elastically when concentrates price decreases.

The farm's total land area has large effect on land allocations and demand for feed concentrates. Feed grain area increases more elastically with the farms total land area than roughage area. Farmers, who expand milk production, shift land from grain to roughage and purchase feed concentrates outside the farm. The amount of labour and farming capital (other than land) have negligible effects on land allocations and demand for purchased feed concentrates.

\section{Concluding remarks}

This paper estimates an econometric model for land allocations, the demand of purchased feed concentrates, and the supply for milk in Finnish dairy-farm records in 1989-1997. The response of land allocations were estimated with respect to acreage based subsidies, prices, and farm characteristics, such as farm size, farm capital and 
Vol. 10 (2001): 285-294.

labour services. Endogeneity of milk output during the period of tradable milk quotas was tested by Hausmann Specification test.

The results suggest that roughage and feed grain land allocations respond sluggishly (inelastically) to the changes in prices and area subsidy rates. Additionally, the demand for purchased feed concentrates responds elastically to the changes in its own price but inelastically to changes in other prices and area subsidy rates. Therefore, the observed intensification of dairy cows' diet is a result primarily from the decreased prices of feed grains and manufactured feeds rather than from unbalanced area subsidy rates. The results do not provide strong grounds on the view that the area subsidy rates paid for roughage and feed grain areas have significantly shifted land from roughage to feed grains and, in turn, increased the share of feed grains in the ruminants diet.

The results support the view that, particularly, farmers expanding milk production utilise decreased feed concentrates prices and size economies. They allocate more land on roughage and increase purchases of feed concentrates. At the same time the share of feed concentrates in the diet of ruminants may have increased, if the demand for purchased feed concentrates had increased faster than land use had concentrated on roughage. Under the ongoing fast structural development of the Finnish dairy sector, the acreage based subsidies seem to be inefficient tools to alter this trend and increase roughage in ruminants diet.

Farm land area has an important effect on dairy-farms' land use and demand for purchased feed concentrates. When the farm area is increased (ceteris paribus) about 50\% of the increased area is allocated to feed grains and about one third to roughage. Milk output in Finnish farms records turned out to be endogenous in 1994-1997. Therefore, the tradable quotas significantly re-allocated production rights to dairyfarmers willing to expand milk production. This may have an important effect on farm land allocation as well.

Acknowledgements. Authors thank an anonymous referee for suggestions to improve the manuscript. The comments of Professor Matti Ylätalo and Docent Matti Ryhänen are appreciated.

\section{References}

Hardie, I.W. \& Parks, J.P. 1997. Land Use with Heterogeneous Land Quality: An Application on an Area Base Model. American Journal of Agricultural Economics 79: 299-310.

Houck, J.P. \& Ryan, M.E. 1972. Supply Analysis for Corn in the United States: The Impact of Changing Government Programs. American Journal of Agricultural Economics 64: 184-191.

Hsiao, C. 1993. Analysis of Panel Data. Economic Society Monographs 11. Cambridge: Cambridge University Press. 246 p.

Kettunen, L. 1995. Finnish Agriculture in 1994. Helsinki: Agricultural Economics Research Institute, Finland. Research Publications 76a. 63 p.

- 1997. Finnish Agriculture in 1996. Helsinki: Agricultural Economics Research Institute, Finland. Research Publications $82 a .64$ p.
- 1998. Finnish Agriculture in 1997. Helsinki: Agricultural Economics Research Institute, Finland. Research Publications $86 a .64$ p.

Lichtenberg, E. 1989. Land Quality, Irrigation Development and Cropping Patterns on the Northern High Plains. American Journal of Agricultural Economics 71: 187-194.

Lidman, R. \& Bawden, L.D. 1974. The Impact of Government Programs on Wheat Acreage. Land Economics 50: 327-335.

Massow, M. von \& Weersink, A. 1993. Acreage Response to Government Stabilization Programs in Ontario. Canadian Journal of Agricultural Economics 41: 1326.

Miller, D.J. \& Platinga, A.J. 1999. Modelling Land Use Decisions with Aggregate Data. American Journal of Agricultural Economics 81: 180-194. 
Niemi, J. \& Pietola, K. Land use response to agricultural policy and market movements

MMM 1993. Yearbook of Farm Statistics. Official Statistics of Finland. Agriculture and Forestry 1993:7. Helsinki: National Board of Agriculture. $251 \mathrm{p}$.

- 1998. Yearbook of Farm Statistics. Official Statistics of Finland. Agriculture and Forestry 1998:5. Helsinki: National Board of Agriculture. 266 p.

Pietola, K.S. \& Myers, R.J. 2000. Investment Under Uncertainty and Dynamic Adjustment in the Finnish Pork Industry. American Journal of Agricultural Economics 82: 956-967.

Pindyck, R.S. \& Rubinfeld, D.L. 1991. Econometric Models and Economic Forecast. New York: McGraw-Hill, 3rd ed. $596 \mathrm{p}$.

Ryhänen, M., Huhtanen, P., Jaakkola, S. \& Ahvenjärvi, S. 1996. EU-jäsenyyden vaikutus maidontuotantoon.
In: Ylätalo, M. (ed.). Maatalousyritysten sopeutuminen EU:ssa vallitseviin hintasuhteisiin. Helsingin yliopiston taloustieteen laitoksen julkaisuja no. 12. p. 79-118.

Vasavada, U. \& Chambers, R.G. 1986. Investment in U.S. Agriculture. American Journal of Agricultural Economics 68: 950-960.

Wooldridge, J.M. 2000. Introductory Econometrics: A Modern Approach. Cincinnati: South-Western College Publishing. 824 p.

Wu, J. \& Brorsen, W.B. 1995. The Impact of Government Programs and Land Characteristics on Cropping Patterns. Canadian Journal of Agricultural Economics 43: 87-104.

\title{
SELOSTUS
}

\section{Tuki- ja hintamuutosten vaikutus maitotilojen pellon käyttöön}

\author{
Jarkko K. Niemi ja Kyösti Pietola \\ MTT (Maa- ja elintarviketalouden tutkimuskeskus)
}

Voimakkaat muutokset karkea- ja väkirehujen hintasuhteissa sekä peltoalatuissa voivat vaikuttaa nautakarjatilojen pellon käyttöön ja nautojen ruokintaan. EU-jäsenyyden myötä tapahtuneiden maatalouspolitiikan muutosten onkin arvioitu johtavan nautakarjatiloilla karkearehujen korvaamiseen rehuviljapohjaisilla väkirehuilla jopa siinä määrin, että nautojen hyvinvointi saattaa heikentyä. Tässä tutkimuksessa selvitettiin ekonometristen mallien avulla, miten pintaalaperusteiset tuet, rehujen hintasuhteet ja tilakoon kasvu ovat vaikuttaneet maidontuotantoa harjoittavien kirjanpitotilojen rehun tuotantoon.

Tulokset tukevat näkemystä, että väkirehujen käyttö nautojen ruokinnassa on lisääntynyt ensisijaisesti EU-jäsenyyden aiheuttaman rehuviljan hinnan alenemisen eikä niinkään pinta-alaperusteisten tukien lisääntymisen vuoksi. Etenkin tuotantoaan laajentaneilla maitotiloilla on hyödynnetty edullista rehuviljaa ja rehuntuotannon mittakaavaetuja keskittymällä nurmen viljelyyn ja lisäämällä ostorehujen käyttöä. Sen sijaan suorat tuet eivät näytä lyhyellä aikavälillä vaikuttavan maitotilojen pellon käyttöön, joka oli melko joustamatonta suhteessa rehuvilja- ja nurmialoille maksettaviin tukiin.

Tutkimustulosten mukaan myös tilakoko merkitsevästi vaikuttaa maitotilojen pellonkäyttöön ja tilan ulkopuolelta ostettavien rehujen määrään. Tilan peltoalan kasvu lisää rehuviljan viljelyä, mutta maidontuotantoa laajennettaessa nurmikasvien viljelyalat kasvavat ja ostorehujen käyttö lisääntyy. Vapautunut maitokiintiöiden kauppa siirtää merkitsevästi tuotanto-oikeuksia kasvuhakuisille maidontuottajille. 